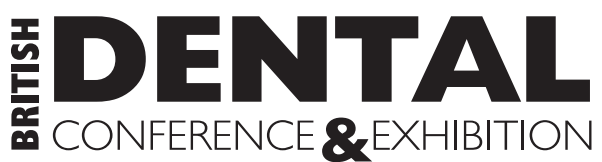

\section{Latest concepts in root canal treatment}

\author{
W. Saunders ${ }^{1}$
}

\author{
This paper highlights one aspect of a presentation to be given at the BDA \\ Conference and is written in the context of dentistry in primary care. Careful oral \\ health assessment as a foundation to good treatment planning and quality \\ dentistry is not new, but there are a number of important new perspectives \\ emerging across countries and healthcare systems in terms of the content and \\ role of such an assessment in modern dental practice.
}

It has been known for 40 years that micro-organisms play an indispensable role in the pathogenesis of periradicular disease. ${ }^{1}$ Seminal studies by Moller et al, ${ }^{2}$ Fabricius et $a l^{3}$ and Sundqvist, ${ }^{4}$ using culturing techniques, showed that the bacteria present in the infected root canal system were mainly obligate anaerobes with smaller numbers of facultative anaerobes. The microflora are varied and interdependent and are present within the necrotic dental pulp and the root canal wall, where they form a complex biofilm. Penetration into the dentinal tubules may occur. These are areas where the host defence mechanisms are lacking. If the latter is compromised, or the micro-organisms are particularly virulent, then invasion of the periradicular tissues may occur. Yeasts and viruses may also be involved with the infective process. ${ }^{5}$

In the last few years it has been demonstrated that the microflora may be even more diverse. Using molecular genetic techniques uncultivatable bacteria have been detected. ${ }^{6,7}$ In addition, teeth with failed root canal treatments may have a different and more resistant flora from de novo cases thereby making success in root canal retreatment more difficult to achieve. ${ }^{8}$

The purpose of root canal treatment is to clean the root canal system of as many pathogens as possible, seal the system to prevent re-infection and allow healing to take place. This must be done without

${ }^{1}$ Professor of Dental Health, University of Dundee's Dental Health Services Research Unit, Community Health Sciences, Mackenzie Building, Kirsty Semple Way, Dundee DD2 4BF

doi:10.1038/sj.bdj.4812297

๑ British Dental Journal 2005; 198: 515-516 compromising the long-term function of the tooth. Shaping the root canal allows cleaning to be undertaken more efficiently as well as providing a suitable shape to obturate the system effectively. The use of nickel titanium rotary instruments allows predictable shapes to be achieved, even in curved root canals. This super elastic alloy has enabled manufacturers to produce instruments of varying taper which can allow improved cleaning. Cleaning is achieved with chemical solutions and sodium hypochlorite $(\mathrm{NaOCl})$ is still the most popular. Removal of the smear layer is considered now to be necessary and a chelating agent such as ethylene diamine tetra acetic acid or citric acid is suitable. A new irrigating solution (MTAD) has shown promising results as an antimicrobial cleaning agent. ${ }^{9-12}$

The apical extent of the root filling influences success. The interface between the periradicular tissues and the pulpal



Fig 1 Radiograph of root filled tooth 17 and 16 following root canal retreatment using heated gutta-percha and sealer. tissues can be determined by electronic apex locators and when used with a precise technique are accurate and reproducible. There has been some controversy concerning the diameter of the apical preparation. Some authorities consider that dentine should be removed apically to remove contamination whilst others consider that a narrow preparation, combined with a suitable flare to allow irrigant penetration is satisfactory. ${ }^{13-16}$ The use of a single visit or multiple visits in root canal treatment continues to generate controversy. Certainly, reversible pulpitis cases can be predictably treated in a single visit but it may be that in cases where there is apical infection that the root canal system should be dressed with an anti microbial agent prior to obturation. ${ }^{17}$

The use of heated gutta-percha for obturation is now commonly accepted (Fig. 1). However, gutta-percha has no effect on the physical properties of the tooth, and materials have been introduced that are said to increase the strength of the tooth root by bonding to the dentine and forming a monobloc. Early tests suggest that these resin materials may have a place in endodontic obturation. ${ }^{18}$ When the root canal system has been obturated it is important to protect it from subsequent microbial contamination. Thus the coronal seal is an important consideration during root canal treatment. ${ }^{19}$ High success rates can be expected. Should re-treatment be necessary, then a surgical approach may be adopted if it is difficult or impossible to reach the apical part of the root canal system from the crown of the tooth. The introduction of microsurgical techniques has transformed this procedure and the 
use of mineral trioxide aggregate as a root end filling ensures that a bioactive healing response may be predicted. ${ }^{20}$

The continued advances in the understanding of the aetiology and treatment of periradicular periodontitis will allow clinicians to achieve more predictable success rates in root canal and root canal re-treatment.

1. Kakehashi S, Stanley H R, Fitgerald R J. The effects of surgical exposures of dental pulps in germ-free and conventional laboratory rats. Oral Surg Oral Med Oral Pathol 1965: 20:340-349.

2. Moller A J, Fabricius L, Dahlen G, Ohman A E, Hayden $G$. Influence on periapical tissues of indigenous oral bacteria and necrotic pulp tissue in monkeys. Scand J Dent Res 1981: 89: 475-484

3. Fabricius L, Dahlen G, Ohman A E, Moller A J R. Predominant indigenous oral bacteria isolated from infected root canal after varied times of closure. Scan J Dent Res 1982; 90:134-144.

4. Sundqvist $G$ Bacteriological studies of necrotic dental pulps (Dr Odont thesis) Umea, Sweden: University of Umea 1976.

5. Peciuliene V, Reynaud A H, Balciuniene I, Haapasalo $\mathrm{M}$. Isolation of yeasts and enteric bacteria in rootfilled teeth with chronic apical periodontitis. Int Endod J. 2001; 34: 429-434

6. Rolph H J, Lennon A, Riggio M P, Saunders W P, MacKenzie D, Coldero, Bagg J. Molecular identification of micro-organisms from endodontic infections. J Clin Microbiol 2001; 39: 3282-3289.
7. Munson M A, Pitt-Ford T, Chong B, Weightman A, Wade W G. Molecular and cultural analysis of the microflora associated endodontic infections. J Dent Res 2002; 81: 761-766.

8. Molander A, Reit C, Dahlen G, Kvist T. Microbiological status of root-filled teeth with apical periodontitis. Int Endod J. 1998; 31: 1-7.

9. Torabinejad M, Shabahang S, Aprecio R, Kettering D. The antimicrobial effect of MTAD: an in vitro investigation. J Endod 2003; 29: 400-403.

10. Shabahang $S$, Pouresmail M, Torabinejad M. In vitro antimicrobial efficacy of MTAD and sodium hypochlorite. J Endod 2003; 29: 450-452.

11. Torabinejad M, Cho Y, Khademi A A, Bakland L K Shabahang $S$. The effect of various concentrations of sodium hypochlorite on the ability of MTAD to remove the smear layer. J Endod 2003; 29: 170-175.

12. Park D S, Torabinejad M, Shabahang S. The effect of MTAD on the coronal leakage of obturated root canals. J Endod 2004; 30: 890-893.

13. Card S J, Sigurdsson A, Orstavick D, Trope M. The effectiveness of increased enlargement in reducing intracanal bacteria. J Endod 2002; 28: 779-783.

14. Wu M K, Wesselink PR, Walton R E Apical terminus location of root canal treatment procedures. Oral Surg Oral Med Oral Pathol Oral Radiol Endod 2000 89: 99-103.

15. Coldero L G, McHugh S, MacKenzie D, Saunders W $P$. Reduction in intracanal bacteria during root canal preparation with and without apical enlargement. Int Endod J 2002; 35: 437-446.

16. Siqueira Junior J F, Lima K C, Magalhaes FA, Lopes $H \mathrm{P}$, de Uzeda M. Mechanical reduction of the bacterial population in the root canal by three instrumentation techniques. J Endod 1999; 25: 332-325
17. Nair P N R, Henry S, Cano V, Vera J. Microbial status of apical root canal system of human mandibular first molars with primary apical periodontitis after "one-visit" endodontic treatment. Oral Surg Oral Med Oral Pathol Oral Radiol Endod 2005; 99: 231-252.

18. Teixeira F B, Teixeira E C, Thompson J Y, Trope M. Fracture resistance of roots endodontically treated with a new resin filling material. J Am Dent Assoc 2004: 135: 646-652.

19. Saunders W P, Saunders E M. The root filling and restoration continuum - prevention of long term endodontic failure. Alpha Omegan 1997; 90 : 40-46

20. Koh E T, McDonald F, Pitt Ford T R, Torabinejad M. Cellular response to Mineral Trioxide Aggregate. Endod. 1998: 24: 543-547.

The British Dental Conference \&t Exhibition 2005 is being held at the Glasgow SECC between Thursday 19th and Saturday 21st May 2005

Contact: DMS (Delegate Management Services) for further information:

Tel: 08701666625 or +44 (0) 1252771425 (overseas)

Fax: 08705228890 or +44 (0) 1252771790 (overseas)

For the latest update on the agenda and to download the programme visit: www.bda-events.org 